This document is the accepted manuscript version of the following article:

Anand Verma, David Martineau, Erwin Hack, Mohammed Makha, Erik Turner, Frank Nüesch and Jakob Heier, Towards industrialization of perovskite solar cells using slot die coating, Journal of

Materials Chemistry C, 2020, DOI:10.1039/D0TC00327A

\title{
Towards industrialization of perovskite solar cells using slot die coating
}

Anand Verma, ${ }^{a}$ David Martineau, ${ }^{b}$ Erwin Hack, ${ }^{c}$ Mohammed Makha, ${ }^{a, d}$ Erik Turner, ${ }^{e}$ Frank Nüesch ${ }^{a, f}$ and Jakob Heier ${ }^{a, *}$

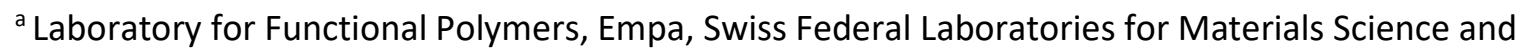
Technology, Überlandstrasse 129, CH-8600 Dübendorf, Switzerland.

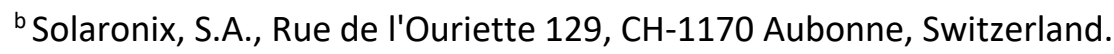

'Transport at Nanoscale Interfaces, Empa, Swiss Federal Laboratories for Materials Science and Technology, Überlandstrasse 129, CH-8600 Dübendorf, Switzerland.

${ }^{d}$ Current address: Materials Science and Nano-engineering Department, Mohammed VI Polytechnic University (UM6P), Lot 660, Hay Moulay Rachid, 43150 Bengurir, Morocco.

${ }^{\mathrm{e}}$ Haldenstrasse 27, $\mathrm{CH}-8955$ Oetwil an der Limmat, Switzerland.

f Institut des Matériaux, École Polytechnique Fédérale de Lausanne, EPFL Station 12, CH-1015

Lausanne, Switzerland.

Corresponding author: Jakob.Heier@empa.ch

$\dagger$ Electronic supplementary information (ESI) available: Video of layer coating by slot die coating, efficiency measurements, cell geometry and surface tension measurement including Figure S1 - S6 and Table S1 - S2.

Keywords: perovskite solar cells, printing, slot die coating, ellipsometry 
The carbon-based hole transport layer-free carbon mesoscopic perovskite solar cell (MPSCs) is considered as cell architecture with high potential for commercialization, due to its enhanced stability. In the standard process for large area and module fabrication, mesoporous layers of $\mathrm{TiO}_{2}$, $\mathrm{ZrO}_{2}$ and carbon are screen printed onto fluorine doped tin oxide (FTO) coated with a compact $\mathrm{TiO}_{2}$ $\left(\mathrm{cTiO}_{2}\right)$ layer. In this work, we sequentially replaced screen printing by slot die coating one by one for all layers until we achieved a fully slot die coated solar cell. Slot die coating is a manufacturing technique with a much higher throughput than screen printing. We demonstrate that slot die coated layers do not need to be sintered separately as opposed to the screen printed layers, but can rather be co-fired for increased manufacturing speed and efficacy. We characterize inks, the coating process, the morphology and performance of these solar cells. The cells show efficiencies comparable to the ones of the screen printed control devices. The cells also show an extraordinary high shelf life stability. We also demonstrate that ellipsometry can be used as an efficient (in-situ) tool to characterize the stack structure of the cells.

\section{Introduction}

Rapid improvement in efficiency of Perovskite solar cells (PSC) in just a few years triggered tremendous research and development efforts in this photovoltaic technology domain. ${ }^{1-9}$ Presently most of the research is focused on exploring materials and device architectures leading to efficiency milestones and device stability. The record perovskite power conversion efficiency to date (NREL efficiency chart from February 18,2020 ) lies at $25.2 \%$ with a so-called planar structure. ${ }^{1}$

The success of commercializing perovskite solar cells relies on key advantages to compete with established photovoltaic technologies. For example, PSCs can be processed from solution, resulting in low production cost and smaller capital expenditure. Historically, perovskites were first used as dye substitutes in dye sensitized solar cells (DSSC), whereby the perovskite crystals grew in the mesoporous scaffold. Based on this device architecture, the carbon-based hole transport layer-free mesoscopic perovskite solar cell (MPSC) was developed. While this cell architecture cannot compete with planar structures in terms of efficiency, excellent device stability was demonstrated for fully screen printed devices. ${ }^{10-13}$ For this device geometry, highest efficiencies have been achieved with a mesoporous metal oxide $\mathrm{TiO}_{2} / \mathrm{Al}_{2} \mathrm{O}_{3} / \mathrm{NiO}$ layered framework with a carbon counter electrode and the triple cation perovskite $\mathrm{Cs}_{0.05}\left(\mathrm{FA}_{0.4} \mathrm{MA}_{0.6}\right)_{0.95} \mathrm{Pbl}_{0.8} \mathrm{Br}_{0.2}$. Devices were tested on an area of $0.129 \mathrm{~cm}^{2}$ and showed a record efficiency of $17.02 \% .{ }^{14}$

The most followed route for up-scaling MPSCs is via screen printing, sometimes including a spray coating process for the $\mathrm{CTiO}_{2}$ layer. ${ }^{12,15}$ The infiltration of methyl ammonium lead iodide $\left(\mathrm{MAPbl}_{3}\right)$ ink 
has been demonstrated using inkjet printing and using slot die coating by Hashmi et al. and Cotella et al., respectively. ${ }^{12,16}$ Due to difficulties in controlling large area film formation, perovskite crystallization and high-quality interfaces, the maximum efficiencies drop dramatically with increasing device area, posing huge challenges to the research community. On the solar module level, poor module design is causing an efficiency drop at larger dimensions. ${ }^{17,18}$

Fully screen printed MPSCs have been manufactured by NTU Singapore, employing manual infiltration of the perovskite precursor ink (efficiencies of their cells reached maximum values of $10.74 \%$ on an active area of $\left.70 \mathrm{~cm}^{2}\right),{ }^{15}$ and Swansea University with screen printed modules showing efficiencies of $6.6 \%{ }^{19}$ Apart from research institutions, a number of start-up companies, but also well-established electronic companies work on the development of perovskite solar cell modules. ${ }^{20}$ Attempts to scale-up other perovskite device architectures range from ink jet printing to slot die coating of individual layers. ${ }^{12,15,21,22}$

Not reported in the literature though is a holistic solution for PSC cell manufacturing, with the requirement to build the complete perovskite solar cell at industrially relevant speeds, preferentially with one and the same technique. While screen printing is comparatively fast and scalable, in terms of processing speed it cannot compete with printing and coating techniques such as gravure printing, flexo printing or slot die coating. ${ }^{23}$

Nevertheless, slot die coating has not surfaced in the literature as a promising coating technique for MPSCs. But, if successfully implemented, all the issues mentioned above can be addressed. Slot die coating is fully compatible with industry standards. ${ }^{24}$ With coating speeds ranging from less than $1 \mathrm{~mm} / \mathrm{min}$ to more than $600 \mathrm{~m} / \mathrm{min}$, it has been very successfully used to manufacture organic solar cells ${ }^{25}$ and has been used to apply single perovskite layers. ${ }^{26}$

Slot die coating is a non-contact large area processing method for the deposition of homogeneous, defect-free wet films with high cross-directional uniformity. ${ }^{27}$ Slot die coating is a pre-metered technique, with the major benefit that the wet film thickness can be preset and precisely calculated from the flow rate of the fluid and the coating speed. Finally, slot die coating is roll-to-roll compatible and stripe module design friendly. This makes slot die coating an a priori useful tool for printed electronics applications. ${ }^{28}$

Slot die coating covers inks within a wide viscosity window ranging from $1 \mathrm{mPas}$ to $10,000 \mathrm{mPas}{ }^{29}$ and final dry thicknesses from a few nanometers to tens of microns can be reached. Of major concern though is the determination of the operation limits which are needed to set the parameters of coating speed, flow rate and coating gap. Even though a couple of theories describe the operation limits, ${ }^{30}$ the mechanism behind coating instabilities is poorly understood. A number of competing forces act on the coating bead, such as capillary, viscous, inertial and elastic forces. ${ }^{31,32}$ An operation near the operation limits can trigger coating defects..$^{24,33}$ 
We here apply the visco-capillary model that only considers the fluid meniscus at the downstream lip of the slot die and is valid when air entrainment is not occurring (Fig. 1). Useful in this context is the introduction of the capillary number $\mathrm{Ca}$, which expresses the coating speed $v$ in a dimensionless form including viscosity $\eta$ and surface tension $\sigma$ of the liquid:

$$
C a=\frac{\eta v}{\sigma}
$$

Above a critical pressure in the coating bead, the film thickness is too low to form a stable wet film. This is the so-called low flow limit. Ruschak developed a theoretical model that defined a critical capillary number above which the flow field of the coating bead between die and substrate becomes unstable: ${ }^{34}$

$$
C a_{\text {crit }}=n\left(\frac{2}{G-1}\right)^{\frac{3}{2}}
$$

whereby $G$ is the ratio of the height of the gap between substrate and lip $h_{G}$ and the thickness of the wet film $h_{\text {wet: }}$ :

$$
G=\frac{h_{G}}{h_{w e t}}
$$

Thus, increasing $G$ will lead to unstable coating for larger capillary numbers.

In this paper we describe the complete fabrication process of MPSC modules with competitive efficiencies using only slot die coating. The inks for slot die coating are based on the pastes developed for screen printing. The different fluid dynamic requirements to the ink make composition adaption necessary, which will alter the final film properties, not to mention differences in wetting, drying and interface formation behavior. Manufacturing of all individual layers, and the influence of ink and solvents will be detailed below, and in the Electronic supplementary information (ESI $\uparrow$ ).

\section{Results and Discussion}

Fig. 2a shows a schematic cross section of the monolithic perovskite solar cell structure. For module manufacturing, small stripes need to be serially connected, which can be realized by printing individual lines with an offset, or by scribing the lines P1, P2 and P3 in a large area coating. Slot die coating allows for large area coating, as well as for "module friendly" stripe coating. The second concept is implemented in our module fabrication process, but only for demonstration purposes. A diagram of the final manufacturing process is shown in Fig. $2 \mathrm{~b}$. To manufacture efficient modules, the line accuracy and width between the stripes would need to be further optimized. Consequently, we 
here also do not report module efficiencies, but rather values for $0.64 \mathrm{~cm}^{2}$ areas on samples cut from the slot die coated substrates (Fig. 2c).

In a first step, inks for all individual layers were developed for slot die coating and the process was optimized for the required layer thicknesses. Images of the inks, substrates coated with stripes of $\mathrm{cTiO}_{2}, \mathrm{mTiO}_{2}, \mathrm{mZrO}_{2}$ and carbon, as well as two videos demonstrating large area coating by slot die coating are shown in Fig. S1 in the ESI $\uparrow$. In a second step, screen printed layers were replaced individually by slot die coated layers, starting from the bottom. Only when the devices reached an efficiency comparable to the reference cell, the next slot die coated layer was implemented. Generally, all individual layers were dried and sintered after deposition. A further highlight of this work is the finding that slot die coating allowed co-firing of the full solar cell stack before perovskite infiltration, presenting the possibility to continuously produce MPSCs with least down time possible. Differently, to reach best efficiencies, screen printed cells required sintering after each deposition step.

To fabricate the reference device, we followed a recipe based on a fully screen-printed stack. ${ }^{35}$ The optimal thickness of the stack has been reported by many research groups. ${ }^{12,15}$

\section{Ink formulation and layer coating}

\section{Compact $\mathrm{TiO}_{2}$}

The compact titania layer acts as a blocking layer in the MPSC structure and thus requires a homogeneous conformal coating, free of defects and pinholes. A specific challenge is the roughness of the FTO substrate, as well as crack formation during drying or due to stress.

The titanium diisopropoxide bis(acetylacetate) precursor (TAA) was used as the basis for ink development. ${ }^{36}$ In the following we exemplarily describe the strategies that led to the formation of a uniform $\mathrm{CTiO}_{2}$ coating. Ink formulation and parameter settings of the slot die coater depend on each other and are matched in several iteration steps. In the first attempt, the TAA precursor ink was slot die coated as supplied onto a FTO glass substrate. Here, a stable meniscus formed between bead and substrate, which is a mandatory prerequisite for successful coating. In our case, even though a stable meniscus was formed, the wet and dry films were very inhomogeneous. Too fast drying of the wet film was identified as cause, the precursor solution was thus diluted with high boiling point (BP) solvents like ethylene glycol (BP: $\left.196^{\circ} \mathrm{C}\right)$, tetralin (BP: $206^{\circ} \mathrm{C}$ ), and xylene (BP: $\left.144^{\circ} \mathrm{C}\right)$. In addition, to reach the desired thickness of $50 \mathrm{~nm}$, a series of concentrations and flow rates were tested. While the first trials with all high boiling inks had yielded immediately a homogeneous wet film, upon drying, the film started to de-wet, showed bad pinning and uneven drying. The result of such a coating with a $\mathrm{TiO}_{2}$ (Tetralin) (1:10) solution are shown in Fig. 3a. Applying the solution a second time 
(wet on wet coating) improved substrate pinning (Fig. 3b). The strategy of solvent mixtures (high and low BP) was adopted to improve thin film formation and counter the de-wetting of the film. Isopropanol alcohol (iPrOH) acted as a low boiling point solvent and tetralin as high boiling point solvent. iPrOH has a $\mathrm{BP}$ of $82.5^{\circ} \mathrm{C}$ and thus can facilitate uniform drying of the coated wet film. The new titania ink contains (Tetralin : iPrOH (1:1 vol) + TAA (1:10)). The modified ink led to a homogeneous wet film, but even after double coating the dried film was very inhomogeneous (Fig. 3c). While adding a low BP co-solvent did alleviate de-wetting problems of the wet film, the addition of an even faster evaporating alcohol like ethanol (EtOH) was used to improve the homogeneity of the film after drying. With the introduction of a fast evaporating solvent to the ink mixture and optimizing the ratio of the solvents, a further improvement of the homogeneity of the dried film was possible (Fig. $3 \mathrm{~d}$ ). A mixture of the three solvents tetralin : $\mathrm{iPrOH}$ : EtOH (TIE) in a 1:1:1 mixture by volume, added with volume fraction of 20:1 to the TAA precursor solution showed good wet as well as dry film formation (Fig. 3e). A line profile through the stripe showed a lower thickness at the edges than at the center due to poor leveling of the thin film. To improve the thin film profile we introduced a fluoro-surfactant to the solvent mixture. Both, wet and dry films were homogeneous with levelled edge profiles as shown in Fig. $3 \mathrm{f}$.

Besides improved pinning, double coating of wet on wet films proved to fill pinholes present in the first layer.

The compositions and printing parameters of the final $\mathrm{TiO}_{2}$ inks that yielded satisfactory coatings are summarized in Table 1 and Table 2, respectively. After coating, the films were dried at $70^{\circ} \mathrm{C}$ for 10 min and $200^{\circ} \mathrm{C}$ for $1 \mathrm{~h}$ and then heated to $500{ }^{\circ} \mathrm{C}$ on a hot plate (under air) to form a compact $\mathrm{TiO}_{2}$ film.

Relevant for device fabrication is the final thickness after firing. The thickness has been determined with profilometry from films coated on glass and was found to be $47 \mathrm{~nm}$ after double coating.

Fig. 4 a shows the critical capillary number describing bead stability during coating as a function of film thickness following Eqn (3). For higher capillary numbers the coating bead became unstable. Due to the low film thickness of $\mathrm{CTiO}_{2}$, slot die coating at that speed is close to the critical value, and may not allow increasing the coating speed further. Besides the criteria decisive for ink development, also substrate wettability can be quantified with the help of wetting envelopes.

Fig. $4 \mathrm{~b}$ shows the wetting envelope of FTO and the surface energies of EtOH, iPrOH, terpineol and tetralin (the solvents utilized during ink development). The surface tensions of the solvents lie well within the wetting envelope for FTO, which at least from a surface energy point of view guarantees proper wetting of the substrate with the ink. 


\section{Mesoporous $\mathrm{TiO}_{2}$}

The $\mathrm{mTiO}_{2}$ layer plays a crucial role in the MPSC, it serves as selective contact for electron extraction and as scaffold for the perovskite crystals. $25 \mathrm{~nm}$ were identified as the optimal diameter for the $\mathrm{TiO}_{2}$ nanoparticles. ${ }^{37}$ The screen printing paste Ti-Nanoxide T165/SP used as base ink has a very high viscosity requiring dilution of the paste to adapt it for the slot die coating process. The paste was diluted first with the base solvent terpineol. Similar to $\mathrm{CTiO}_{2}$, this led to very slow drying and nonhomogeneous film formation. To initiate fast drying as well as to keep the nanoparticle mesoporous ink suspension stable, solvents from the alcohol group only were added. Experiments were performed with iPrOH and $\mathrm{EtOH}$. iPrOH led to very homogeneous wet as well as dry films. Ink composition and properties and processing conditions are summarized in Table 1 and Table 2. The low surface energy of the underlying $\mathrm{CTiO}_{2}$ makes wetting of the ink a more challenging task, while the coating bead is in the stable region and would allow for a higher coating speed Fig. 4a. The deposited layers were then dried at $110^{\circ} \mathrm{C}$ for $10 \mathrm{~min}$ and fired at $500^{\circ} \mathrm{C}$ for $1 \mathrm{~h}$ on a hot plate.

\section{Mesoporous $\mathrm{ZrO}_{2}$}

The absence of a hole transport layer makes the introduction of a spacer layer between $\mathrm{mTiO}_{2}$ and carbon necessary to avoid short cuts in the cell. $\mathrm{ZrO}_{2}$ is frequently chosen for that purpose for its large band gap and the formation of large pores when processed from nanoparticle inks, that facilitates the infiltration with perovskites. Following the same strategy as for the development of the ink for the $\mathrm{mTiO}_{2}$ layer, the zirconia ink was developed (Table 1). The ink has a viscosity of $17.5 \mathrm{mPa} . \mathrm{s}$ and a surface tension of $25.9 \mathrm{mN} / \mathrm{m}$. The desired thickness of $1000 \mathrm{~nm}$ was reached using the ink with two times wet on wet coating with a speed of $0.9 \mathrm{~m} / \mathrm{min}$ and a flow rate of $1.25 \mathrm{ml} / \mathrm{min}$ (Table 2). The wet film was then dried at $110^{\circ} \mathrm{C}$ for $10 \mathrm{~min}$ at ambient conditions, and fired at $500^{\circ} \mathrm{C}$ for $1 \mathrm{~h}$ on a hot plate.

\section{Carbon back electrode}

In the MPSC architecture, the carbon layer acts as hole collector as well as electrode. The required 12 $\mu \mathrm{m}$ film thickness after firing is still within the range of slot die coating. The screen printing paste was optimized with addition of $\mathrm{EtOH}$ and $\mathrm{iPrOH}$ to reach good flowability and meniscus formation during slot die coating (Table 1). The ink was deposited with a speed of $0.2 \mathrm{~m} / \mathrm{min}$ and a flow rate of 0.2 $\mathrm{ml} / \mathrm{min}$ and dried at $110^{\circ} \mathrm{C}$ for $10 \mathrm{~min}$. This procedure led to the formation of a homogeneous wet film, and a 10-12 $\mu \mathrm{m}$ thick film after firing (Table 2). We believe that due to non-Newtonian behavior of the ink, the meniscus broke sometimes when coated at speeds in excess of $1 \mathrm{~m} / \mathrm{min}$ and 
sometimes it led to inhomogeneities in the wet film. The developed carbon ink has a surface tension of $23.4 \mathrm{mN} / \mathrm{m}$ as shown in Table 1.

\section{Cell manufacturing, co-firing and infiltration}

After optimizing the slot die coating parameters of individual layers of the device stack, solar cell devices were fabricated on FTO substrates. One set of fully slot die coated samples was prepared, where the completed stack was co-fired at $450^{\circ} \mathrm{C}$, skipping the individual firing steps after deposition of each layer. For characterization, smaller cells were cut out of from the substrates (Fig. 2c).

The metal oxide/carbon scaffold was infiltrated with $\mathrm{MAPbl}_{3}$ with 5-ammonium valeric acid iodide (5AVAI) additive, which forms mixed-cation perovskite (5-AVAI)x(MA)1-xPbl ${ }_{3}$ crystals with lower defect concentration, better pore filling and a more complete contact with the $\mathrm{TiO}_{2}$ scaffold as compared to single cation $\mathrm{MAPbl}_{3}{ }^{35}$ The complete cells were incubated by a humidity assisted thermal treatment. $^{38}$

\section{Characterization}

\section{X-ray scattering}

To prove the full conversion of the perovskite precursor solution into perovskite, and to exclude decomposition of perovskite into $\mathrm{Pbl}_{2}, \mathrm{XRD}$ measurements were performed on the infiltrated samples. The spectrum is dominated by the diffraction peak of the $\mathrm{TiO}_{2}$ anatase peak at $2 \Theta=25.3^{\circ}$. A zoom into the spectrum shows all characteristic perovskite peaks, while no peak at the position of $\mathrm{Pbl}_{2}\left(2 \Theta=12 \cdot 5^{\circ}\right)$ can be identified (Fig. 5).

\section{Cell morphology}

Cross-sections of the samples were imaged with Scanning Electron Microscopy (SEM), Fig. 6. Noticeable is a strong layering within the carbon layer, with large graphite flakes aligning parallel to the $\mathrm{mZrO}_{2}$ surface. ${ }^{39}$ Important seems a solid infiltration of the carbon layer with perovskite. A zoom into the metal oxide layers shows a very similar grain structure of nanoparticles about $100 \mathrm{~nm}$ in diameter for both $\mathrm{mTiO}_{2}$ and $\mathrm{mZrO}_{2}$, whereby the interface between the two materials can be hardly identified. The SEM images speak for a uniform infiltration and crystallization of the mesoporous metal oxide structure, even though differences between non-infiltrated and infiltrated cells are hardly detectable (Fig. S2 in the $\mathrm{ESI}+$ ). The $\mathrm{CTiO}_{2}$ is too thin to be resolved in SEM, but a dark line follows the interface between $\mathrm{mTiO}_{2}$ and FTO. The interface is rather rough, originating from the granular structure of the FTO. ${ }^{40}$ 
The importance of the morphology of the $\mathrm{CTiO}_{2}$ hole blocking layer had been pointed out. The $\mathrm{CTiO}_{2}$ coating must be defect free at lowest thickness to avoid additional series resistance. ${ }^{41}$ For that reason an analysis of the FTO surface and the $\mathrm{TiO}_{2}$ layers applied to FTO by slot die coating was performed by AFM and compared to $\mathrm{CTiO}_{2}$ films applied by other coating techniques (Table 3, AFM images Fig. 7). The roughness values of the $\mathrm{CTiO}_{2}$ films applied by spray pyrolysis were closest to the values of the FTO substrate, while slot die coating is most successful in smoothening the FTO surface. Here, a contour-chasing deposition technique would be more favorable, as long as the film is defectfree. XRD proved that independent of the coating technique similar $\mathrm{CTiO}_{2}$ crystals formed (Fig. S3 in the ESI $\dagger$ ).

AFM images of $\mathrm{mTiO}_{2}, \mathrm{mZrO}_{2}$ and Carbon surfaces are shown Fig. 8. The $\mathrm{mTiO}_{2}$ and $\mathrm{mZrO}_{2}$ surfaces look alike, the similarity of the morphology of the two materials was already observed with SEM. Profiles of the scans show that slot die coating of $\mathrm{mTiO}_{2}$ and $\mathrm{mZrO}_{2}$ results in flat and smooth layers. Differently, the slot die coated carbon layer still shows a high surface roughness.

\section{Analysis with ellipsometry}

Spectrosopic ellipsometry allows obtaining layer parameters from non-destructive measurements on the sample as manufactured under ambient conditions and would be compatible with an in-line assessment of the production quality. The optical parameters of the glass substrate was obtained after removal of the FTO layer and was comparable to a BAK-1 glass. The FTO coating was modelled starting from the structure reported in $\mathrm{REF}{ }^{42}$. This model includes two thin layers of $\mathrm{SnO}_{2}$ and $\mathrm{SiO}_{2}$ between the glass and the FTO layer. It was noted that the FTO layer had much less absorption in the near infrared compared to the values from the J.A.Woollam database. Adapting the corresponding Drude term by reducing the resistivity to $0.0004 \Omega \mathrm{cm}$ and increasing the scattering time to $7.5 \mathrm{fs}$ led to a better fit and was in agreement with the fact that high conductivity FTO was selected for the PV devices. We further found a hint towards a fluorine reduced top layer which was accommodated by a grading of the FTO layer. The final FTO substrate model consisted of the glass substrate, a $32 \mathrm{~nm}$ thick $\mathrm{SnO}_{2}$ layer followed by $25 \mathrm{~nm}$ of $\mathrm{SiO}_{2}$ and a total of $370 \mathrm{~nm}$ of FTO. Finally, a roughness of around $33 \mathrm{~nm}$, Table 3, could be confirmed.

When depositing a layer of compact $\mathrm{TiO}_{2}$ on top of the FTO substrate, the roughness turns into an effective medium approximation (EMA) layer made up of the $\mathrm{CTiO}_{2}$ and the FTO material. As deposited, a cTiO 2 thickness of $175 \mathrm{~nm}$ was measured, irrespective of the layer being modeled as a homogeneous oxide or a $\mathrm{TiO}_{2}$ layer with $40 \%$ porosity in the EMA according to Bruggeman, ${ }^{43}$ Table 4 , Fig. 9.

The printed layer of $\mathrm{mTiO}_{2}$ on top of the $\mathrm{CTiO}_{2}-\mathrm{FTO}$ stack was added to the ellipsometer model, and a layer thickness of $800 \mathrm{~nm}$ with $15 \mathrm{~nm}$ roughness was fitted. The final layer of $\mathrm{ZrO}_{2}$ appeared 
inhomogeneous and measurements at different locations yielded a thickness variation of $570-800$ $\mathrm{nm}$. This thickness variation was most probably caused by the printing process itself.

In the sintered samples the layer structure changed strongly. For the first $\mathrm{cTiO}_{2}$ layer, a good fit is obtained for a thickness of only $32 \mathrm{~nm}$ with $15 \%$ void content, while the FTO layer with a fluorine poor grading towards the top is confirmed. When the $\mathrm{mTiO}_{2}$ layer is added and sintered, a layer thickness of $500 \mathrm{~nm}$ with $50 \%$ void content is modeled. Finally, the $\mathrm{ZrO}_{2}$ layer is reasonably well fitted with a mere $175 \mathrm{~nm} \mathrm{ZrO}$ thickness, again with a high void content of $>50 \%$. This value is inconsistent with data from SEM, at the moment we have no satisfying explanation for this.

Rather than sintering the device layer by layer after each printing pass, the entire stack was co-fired. The resulting layer thickness values have a tendency to be larger than the ones from individually sintered layers, and show a slightly higher void content, see Table 5 . The ellipsometry layer model is based on a mixture of oxide and void according to the effective medium approximation to explain the lowering of the refractive index. While this model is inspired from a layer with porosity, the change of the refractive index can also be caused by a change in oxide content.

\section{Photovoltaic properties}

Photovoltaic parameters of the reference cell, the development cells and the fully slot die coated cells are shown in Table 6 and Fig. 10. The values are based on reverse scans. Typical J-V curves of a forward and reverse scan of fully slot die coated cells are shown in Fig. 11. We show a device of the first generation with a lower efficiency. The devices showed hysteresis, also reflected in the different fill factors. The reference cell (fully screen printed) reached an average efficiency of $\eta=12.3 \%$, with $\mathrm{J}_{\mathrm{sc}}=23.7 \mathrm{~mA} \mathrm{~cm}^{-2}, \mathrm{~V}_{\mathrm{oc}}=0.92 \mathrm{~V}$ and $\mathrm{FF}=66 \%$

When replacing the screen printed compact $\mathrm{TiO}_{2}$ layer with a slot die coated $\mathrm{TiO}_{2}$ layer (1 layer $\mathrm{SC}$ ), a large drop in efficiency was observed. This is mainly due to reduction of $\mathrm{J}_{\mathrm{sc}}$ from $\mathrm{J}_{\mathrm{sc}}=23.7 \mathrm{~mA} \mathrm{~cm} \mathrm{co}^{-2}$ to $\mathrm{J}_{\mathrm{sc}}=19.1 \mathrm{~mA} \mathrm{~cm}^{-2}$. The explanation is rather straightforward: the slot die coated $\mathrm{cTiO}_{2}$ layer does not form a conformal thin coating on top of the FTO, but rather fills the valleys, and introduces a serial resistance. A minor drop of $\mathrm{V}_{\text {oc }}$ may be due to the slight change in the chemical composition of the slot die coated $\mathrm{TiO}_{2 .}{ }^{44,45}$

Interestingly, this negative effect was partially compensated when more metal oxide layers were applied by slot die coating (2 layers SC and 3 layers $S C$ ). $V_{\text {oc }}$ remained more or less constant, that indicates that the contact potential difference between hole and electron transport materials did not change and the $\mathrm{ZrO}_{2}$ insulation layer successfully prevented charge recombination. More difficult to explain is the simultaneous increase of $\mathrm{J}_{\mathrm{sc}}$ and decrease of fill factor. Assuming a similar geometry of the samples, high reverse saturation current or high ideality can be excluded, as this would also affect $V_{\text {oc. }}$. Higher series resistance or lower shunt resistance would not increase $\mathrm{J}_{\text {sc. }}$. For a complete 
understanding of the processing happening at the interfaces, a more detailed analysis of processes would be necessary, which is beyond the scope of this paper.

Moving to fully slot die coated devices, the trend from before was reversed: both $J_{s c}$ and $V_{o c}$ decreased while the fill factor increased. Here the alignment of graphite flakes parallel to the substrate during slot die coating could be of disadvantage for current extraction. The fully slot die coated and co-fired samples showed the poorest performance, with efficiencies of $\eta=11.1 \%$, but also the scatter in data is largest. Reason for the poor performance may be found in the interfaces that get more diffuse during co-firing.

We want to point out that also comparing efficiency values of our cells to current state-of-the art values proved difficult due to the absence of a standard measurement protocol, the strong dependence of measured efficiency on cell area, the detailed measurement routine ${ }^{46}$ but also differences in cell manufacturing from laboratory to laboratory. This is also reflected in a large scatter in reported record efficiencies. Parameters of the best performing MPSC cells were reported as $\mathrm{J}_{\mathrm{sc}}=23.40 \mathrm{~mA} / \mathrm{cm}^{2}, \mathrm{~V}_{\mathrm{oc}}=1.08 \mathrm{~V} ; \mathrm{FF}=0.72$ and power conversion efficiency $(\mathrm{PCE})=17.02 \%$ on small areas $\left(0.129 \mathrm{~cm}^{2}\right)$, whereby cells were manufactured by a combination of spray pyrolysis, screen printing and dipping. ${ }^{14}$ Differently, the champion cell reported by Hashmi et al. fabricated by similar means, but infiltration of perovskite by ink jet printing remained below $10 \%{ }^{12}$

To evaluate the robustness of our measurement protocol, we followed different measurement routines for a number of selected cells (Table S1 in the ESI $\dagger$ ). It had been suggested to also report the efficiency from maximum power point tracking (mpp, Fig. S4 in the ESI $\uparrow$ ). ${ }^{47}$

Furthermore, we investigated the long-term device stability of slot die coated devices (Fig. 12). The slot die coated devices showed incredible shelf life stability when stored under ambient conditions. Non-encapsulated devices were stable for one year and only showed signs of degradation after that. The main cause of efficiency loss was the fill factor. The encapsulated devices were stable for more than two years. This indicates the stability of the slot die coated films and interfaces between the different layers of the device stack.

\section{Conclusions}

We have demonstrated the development of a truly industrial coating process for the fabrication of perovskite solar cells. All layers of the mesoporous hole transport free carbon-based perovskite solar cell architecture were applied by slot die coating in stripes and on areas up to $10 \times 10 \mathrm{~cm}$. Differently from other coating techniques, a process developed for a small area can be directly scaled-up to larger areas, depending on slot width and table length of the instrument. The PCE of the best 
performing cells exceeds $12 \%$ and is thus in the range of the values reported for cells manufactured by screen printing, which is the standard manufacturing process for this cell architecture. We also suggest spectroscopic ellipsometry as a powerful in-line characterization tool which can deliver similar information as AFM and SEM. Inks for slot die coating are more dilute and contain a smaller volume fraction of binders. That posed serious challenges in the multi-layer printing process in terms of de-wetting during drying, but was rewarded with a coating process that has tremendous advantages over screen printing, starting at the coating speed, but also at the ink composition.

The low binder content proved most advantageous for attempts to co-fire the entire layered stack after printing. This process yielded very poor results with screen printed samples while slot die coated solar cells showed a minor decrease in efficiency, but a major reduction in processing time.

We have also demonstrated an excellent shelf-life stability of fully slot die coated cells exceeding 1 year when stored under ambient conditions.

Next steps to bring this manufacturing process closer to commercialization includes the use of laser ablation for interconnect locations (P1, P2 and P3, see Fig. 2) to achieve higher active areas, the deposition of $\mathrm{MAPbl}_{3}$ using slot die coating to make use of one coating technique for all layers, and improve the efficiency of film drying for roll-to-roll processing.

\section{Experimental Section}

\section{Printing equipment}

Slot die coating was performed on a TSE Troller (Switzerland) table top slot die coater, with a $50 \mathrm{~mm}$ wide slot die with integrated shim foils to define a line pattern.

Screen printing was performed on a DEK148 printer with different meshes as specified below.

\section{Materials}

For all inks, screen printing pastes commercially available from Solaronix, SA, Switzerland, were used as base material. For the $\mathrm{CTiO}_{2}$ layer, the titania precursor ink titanium diisopropoxide bis(acetylacetonate), $75 \mathrm{wt} \%$ in isopropanal (Sigma Aldrich) was applied, for the $\mathrm{mTiO}_{2}$ layer, the titania paste Ti-Nanoxide T165/SP (Solaronix, Switzerland) was utilized, for the $\mathrm{mZrO}_{2}$ layer, the zirconia paste Zr-Nanoxide ZT/SP (Solaronix, Switzerland) was used. The carbon paste Elcocarb B/SPis a mixture of 25 wt\% of carbon nanoparticles and graphite flakes (Solaronix, Switzerland). 


\section{Device fabrication}

The MPSC solar cell stack consists of a multilayer system of $\mathrm{cTiO}_{2}(50 \mathrm{~nm}), \mathrm{mTiO}_{2}(500 \mathrm{~nm}), \mathrm{mZrO}_{2}$ $(1000 \mathrm{~nm})$ and Carbon $(10-12 \mu \mathrm{m})$.

Devices were fabricated on $100 \mathrm{~mm} \times 100 \mathrm{~mm}$ glass plates coated with laser patterned FTO. The substrates were cleaned by sequential sonication in $\mathrm{DI}$ water with $\mathrm{pH}$ neutral surfactant, acetone, and isopropanol. After wet cleaning, the substrates were dried with pressurized air and heated to $110{ }^{\circ} \mathrm{C}$ for more than $10 \mathrm{~min}$ to remove moisture. The FTO glass was also oxygen plasma cleaned to remove any organic residue.

The reference cells were fabricated by semi-automatic screen printing one layer after each other. On the $100 \mathrm{~mm} \times 100 \mathrm{~mm}$ substrate, an array of 18 squares, $10 \mathrm{~mm} \times 10 \mathrm{~mm}$ in size were defined by the stencil (Fig. S5 in the ESI†). Ti-Nanoxide BL150/SP, Ti-Nanoxide T165/SP, Zr-Nanoxide ZT/SP and Elcocarb B/SP were printed using a 150-30, 165-30, 90-48 and 43-80 mesh stencil, respectively. The screen printing inks of $\mathrm{mTiO}_{2}$ and $\mathrm{mZrO}_{2}$ are composed of metal oxide nanoparticles with a diameter of $20 \mathrm{~nm}$, and nano-particular carbon about $30 \mathrm{~nm}$ in size. The graphite flakes are in the range of several microns.

After printing the wet film, each sample was allowed to dwell for $10 \mathrm{~min}$ before drying at $120^{\circ} \mathrm{C}$ for $10 \mathrm{~min}$, followed by a firing step at $500^{\circ} \mathrm{C}$ (or $400^{\circ} \mathrm{C}$ for carbon) for $30 \mathrm{~min}$, after a $30 \mathrm{~min}$ ramp.

For the development of suitable inks, we fabricated devices (hereafter called development cells), where the screen printed layers of the reference device were sequentially replaced by slot die coated layers, starting from the bottom, until all layers were slot die coated. The slot die layers consisted of stripes with a width of $15 \mathrm{~mm}$ ( $\mathrm{cTiO}_{2}, \mathrm{mZrO}_{2}$ ) or $14 \mathrm{~mm}$ (all other layers) defined by a shim foil. The $\mathrm{mZrO}_{2}$ and carbon layers were printed with an offset to fill the P1 scribe or connect to the FTO layer over the P1 scribe, respectively, as shown Fig. 2a. Similar to the reference cells, the screen printed layers consisted of 18 squares defined by the mesh. The following sample sets were fabricated: $\mathrm{CTiO}_{2}$ slot die coated, $\mathrm{mTiO}_{2}, \mathrm{mZrO}_{2}$ and Carbon screen printed (1 layer SC); $\mathrm{cTiO}_{2}$ and $\mathrm{mTiO}_{2}$ slot die coated, $\mathrm{mZrO}_{2}$ and Carbon screen printed (2 layers $\mathrm{SC}$ ); $\mathrm{cTiO}_{2}, \mathrm{mTiO}_{2}$ and $\mathrm{mZrO}_{2}$ slot die coated, Carbon screen printed ( 3 layers SC). After coating the wet film, the screen printed layers were allowed to dwell for $10 \mathrm{~min}$ before drying at $120^{\circ} \mathrm{C}$ for $10 \mathrm{~min}$, followed by a firing step at $500^{\circ} \mathrm{C}$ (or $400^{\circ} \mathrm{C}$ for carbon) for $30 \mathrm{~min}$, after a $30 \mathrm{~min}$ ramp. The slot die coated layers were dried at $70^{\circ} \mathrm{C}$ for $\mathrm{CTiO}_{2}$ and $110^{\circ} \mathrm{C}$ for the other layers for $10 \mathrm{~min}$, and sintered at $500^{\circ} \mathrm{C}$ (or $400^{\circ} \mathrm{C}$ for carbon) for $30 \mathrm{~min}$. The $\mathrm{CTiO}_{2}$ layer requires an additional drying step where the $\mathrm{CTiO}_{2}$ coated films were heated to $200^{\circ} \mathrm{C}$ for $1 \mathrm{~h}$ before high temperature sintering. The lateral edges were defined by laser etching in order to form a rectangle similar to the screen printed electrodes. Only when the devices reached an efficiency comparable to the efficiency of the reference cell, the next slot die coated layer was implemented. Ink development work is described in detail in the results and discussion section. 
In the fully slot die coated cells (FULLYSC), all layers were deposited by slot die coating and sintered individually.

In co-fired slot die coated cells (co-fired SC), all metal oxide layers were printed and dried, and the fully slot die coated stack was then co-fired at $450^{\circ} \mathrm{C}$ for $1 \mathrm{hr}$ on a hotplate. Finally the carbon ink was applied and heated to $400^{\circ} \mathrm{C}$ for $30 \mathrm{~min}$. Coating was performed in a class 6 cleanroom.

\section{Infiltration with perovskite}

The freshly fired electrodes were masked with an adhesive polyimide gasket (Solaronix) to delimit the wet area. An empirically determined volume of $5.76 \mu \mathrm{L}$ of perovskite precursor solution was dropped in the center of each electrode using a micropipette. The solution was a methylammonium lead iodide perovskite precursor salt with 5-aminovaleric acid iodide (5-AVAI) additive (Solaronix). The precursor salt was re-dissolved at $70^{\circ} \mathrm{C}$ right prior to use ${ }^{48}$. The infiltration of $\mathrm{MAPbl}_{3}$ ink was done using a homemade semi- automated dispensing system. Infiltration is very critical and thus automating the process assures reproducible process, eliminating manual interference. The developed automated robotic dispensing system thus insures controlled drop volume, timing, height of drop release and overall reproducibility. The wet samples were then moved to an oven set to $50^{\circ} \mathrm{C}$ where they dried for $60 \mathrm{~min}$, hereby forming the perovskite crystals in the porous electrode structure. The polyimide adhesive gasket was carefully peeled off, and the resulting solar cells were submitted to heat and damp treatment at $40^{\circ} \mathrm{C}$ and $75 \%$ r.h. for 150 h. ${ }^{38}$ Special precautions were taken to avoid lead contamination, e.g. infiltration was done in a glove box dedicated to work on perovskites.

\section{Characterization}

Viscosity and density of the inks were measured on a falling ball viscometer from Anton Paar (LOVIS $2000 \mathrm{ME})$.

Surface tension of the inks was characterized with a drop shape analyzer from Krüss (Fig. S6 in the $\mathrm{ESI} \dagger)$.

Surface tension and wetting envelope of the individual layers were determined by following the theory of Owens, Wendt, Rabel and Kaelble ${ }^{49}$ and measuring the contact angle of water and diiodomethane on the surface to be investigated. Water has $51 \mathrm{mN} / \mathrm{m}$ of polar component and 21.8 $\mathrm{mN} / \mathrm{m}$ of disperse component adding up to $72.8 \mathrm{mN} / \mathrm{m}$ surface tension. Diiodomethane on the other hand is a non-polar solvent with $50.8 \mathrm{mN} / \mathrm{m}$ of disperse component.

The thickness of the layers was determined with a profilometer (XP-1 Surface Profilometer, Ambios Technology). The surface topography was characterized by atomic force microscopy (ICON3 from Bruker) in tapping mode. 
SEM images were taken with a FEI NanoSEM 230.

The crystallization behavior of the nanoparticles as well as the perovskite formation in the mesoporous structure were analyzed by XRD (Pan Analytics, X'Pet pRO).

Slot die printed samples were characterized after addition of each layer before and after sintering using a spectroscopic ellipsometer (J.A. Woollam M-2000VI). Areas on the samples were identified by visual inspection where the coating seemed homogeneous. Measurements were performed at three incidence angles of $50^{\circ} / 60^{\circ} / 70^{\circ}$. All samples were prepared with a scotch tape on the backside to prevent backside reflections from reaching the detector.

Solar cell performance of the screen printed cells was measured on cells of $12 \mathrm{~mm} \times 12.5 \mathrm{~mm}$ active area, solar cell performance of the slot die coated cells was measured on cells about $12 \mathrm{~mm} \times 12.5$ $\mathrm{mm}$ in size cut out of stripes. Silver paste was applied on both anode and cathode sides for current collection. The solar cells were fitted with an opaque black adhesive vinyl mask bearing a $0.64 \mathrm{~cm}^{2}$ aperture (Solaronix), and measured in a SolarSim 150 solar simulator (Solaronix) calibrated to 1000 $\mathrm{W} / \mathrm{m}^{2}$. The voltage was scanned between -0.3 and $1 \mathrm{~V}$, in $5 \mathrm{mV}$ increments every $1.2 \mathrm{~s}$. For comparison, this slow scanning method was compared to another protocol and to maximum power point tracking as well as to efficiency monitoring at constant voltage (Fig. S4 in the ESI $†$ ).

\section{Conflicts of Interest}

There are no conflicts to declare.

\section{Acknowledgements}

We greatly acknowledge funding from the Swiss Federal Office of Energy (SFOE) under the grant numbers SI/501237 and SI/50 1816-01. We acknowledge the use of the facilities of the Coating Competence Center (CCC) and the Scanning User Lab (SUL) at Empa. We thank S. Anantharaman (Empa) for AFM images, S. Abdolhosseinzadeh for SEM images and F. Fu (Empa) for MPP measurements. 


\section{References}

1. Chart of Best Research-Cell Efficiencies Provided by NREL, https://www.nrel.gov/pv/assets/pdfs/best-research-cell-efficiencies.20200218.pdf

2. M. Saliba, T. Matsui, K. Domanski, J.-Y. Seo, A. Ummadisingu, S. M. Zakeeruddin, J.-P. Correa-Baena, W. R. Tress, A. Abate, A. Hagfeldt and M. Gratzel, Science, 2016, 354, 206-209.

3. A. Kojima, K. Teshima, Y. Shirai and T. Miyasaka, Journal of the American Chemical Society, 2009, 131, 6050-+.

4. $\quad$ N. Ahn, D.-Y. Son, I.-H. Jang, S. M. Kang, M. Choi and N.-G. Park, Journal of the American Chemical Society, 2015, 137, 8696-8699.

5. N. J. Jeon, J. H. Noh, W. S. Yang, Y. C. Kim, S. Ryu, J. Seo and S. I. Seok, Nature, 2015, 517, 476-+.

6. D. Bi, C. Yi, J. Luo, J.-D. Decoppet, F. Zhang, S. M. Zakeeruddin, X. Li, A. Hagfeldt and M. Gratzel, Nature Energy, 2016, 1.

7. P. Gao, M. Gratzel and M. K. Nazeeruddin, Energy \& Environmental Science, 2014, 7, 2448-2463.

8. G. Grancini, C. Roldan-Carmona, I. Zimmermann, E. Mosconi, X. Lee, D. Martineau, S. Narbey, F. Oswald, F. De Angelis, M. Graetzel and M. K. Nazeeruddin, Nature Communications, 2017, 8.

9. D. P. McMeekin, G. Sadoughi, W. Rehman, G. E. Eperon, M. Saliba, M. T.

Hoerantner, A. Haghighirad, N. Sakai, L. Korte, B. Rech, M. B. Johnston, L. M. Herz and H. J. Snaith, Science, 2016, 351, 151-155.

10. Z. N. Song, S. C. Watthage, A. B. Phillips and M. J. Heben, Journal of Photonics for Energy, 2016, 6.

11. S. G. Hashmi, A. Tiihonen, D. Martineau, M. Ozkan, P. Vivo, K. Kaunisto, V. Ulla, S. M. Zakeeruddin and M. Graetzel, Journal of Materials Chemistry A, 2017, 5, 47974802.

12. S. G. Hashmi, D. Martineau, X. Li, M. Ozkan, A. Tiihonen, M. I. Dar, T. Sarikka, S. M. Zakeeruddin, J. Paltakari, P. D. Lund and M. Gratzel, Advanced Materials Technologies, 2017, 2.

13. Z. L. Ku, Y. G. Rong, M. Xu, T. F. Liu and H. W. Han, Scientific Reports, 2013, 3.

14. S. Liu, W. Huang, P. Liao, N. Pootrakulchote, H. Li, J. Lu, J. Li, F. Huang, X. Shai, X. Zhao, Y. Shen, Y.-B. Cheng and M. Wang, Journal of Materials Chemistry A, 2017, 5, 22952-22958.

15. A. Priyadarshi, L. J. Haur, P. Murray, D. C. Fu, S. Kulkarni, G. C. Xing, T. C. Sum, N. Mathews and S. G. Mhaisalkar, Energy \& Environmental Science, 2016, 9, 3687-3692.

16. G. Cotella, J. Baker, D. Worsley, F. De Rossi, C. Pleydell-Pearce, M. Carnie and T. Watson, Solar Energy Materials and Solar Cells, 2017, 159, 362-369.

17. A. Di Carlo, F. Matteocci, S. Razza, M. Mincuzzi, F. Di Giacomo, S. Casaluci, D. Gentilini, T. M. Brown, A. Reale, F. Brunetti, A. D'Epifanio, S. Licoccia, 14th IEEE International Conference on Nanotechnology, 2014, p. 70-72.

18. F. Matteocci, L. Cina, F. Di Giacomo, S. Razza, A. L. Palma, A. Guidobaldi, A. D'Epifanio, S. Licoccia, T. M. Brown, A. Reale and A. Di Carlo, Progress in Photovoltaics, 2016, 24, 436-445.

19. F. De Rossi, J. A. Baker, D. Beynon, K. E. A. Hooper, S. M. P. Meroni, D. Williams, Z. Wei, A. Yasin, C. Charbonneau, E. H. Jewell and T. M. Watson, Advanced Materials Technologies, 2018, 3.

20. A. Extance, Nature, 2019, 570, 429-432. 
21. L. H. Cai, L. S. Liang, J. F. Wu, B. Ding, L. Gao and B. Fan, Journal of Semiconductors, 2017, 38.

22. T. Supasai, N. Henjongchom, I. M. Tang, F. Deng and N. Rujisamphan, Solar Energy, 2016, 136, 515-524.

23. K. Suganamu, Introduction to Printed Electronics, Springer Science+Business Media, New York, 2014.

24. Liquid Film Coating: Scientific principles and their technological implications, Springer Science \& Business Media, 2012.

25. F. C. Krebs, Solar Energy Materials and Solar Cells, 2009, 93, 394-412.

26. K. Hwang, Y. S. Jung, Y. J. Heo, F. H. Scholes, S. E. Watkins, J. Subbiah, D. J. Jones, D. Y. Kim and D. Vak, Advanced Materials, 2015, 27, 1241-1247.

27. T. T. Larsen-Olsen, B. Andreasen, T. R. Andersen, A. P. L. Bottiger, E. Bundgaard, K. Norrman, J. W. Andreasen, M. Jorgensen and F. C. Krebs, Solar Energy Materials and Solar Cells, 2012, 97, 22-27.

28. R. R. Sondergaard, M. Hosel and F. C. Krebs, Journal of Polymer Science Part BPolymer Physics, 2013, 51, 16-34.

29. T. D. Blake, Journal of Colloid and Interface Science, 2006, 299, 1-13.

30. X. Ding, J. Liu and T. A. L. Harris, Aiche Journal, 2016, 62, 2508-2524.

31. O. J. Romero, L. E. Scriven and M. S. Carvalho, Journal of Non-Newtonian Fluid Mechanics, 2006, 138, 63-75.

32. H.-M. Chang, Y.-R. Chang, C.-F. Lin and T.-J. Liu, Polymer Engineering and Science, 2007, 47, 1927-1936.

33. E. B. Gutoff and E. D. Cohen, Coating and Drying Defects: Troubleshooting Operating Problems, John Wiley \& Sons, New York, 2nd Edition edn., 2006.

34. K. J. Ruschak, Chemical Engineering Science, 1976, 31, 1057-1060.

35. A. Mei, X. Li, L. Liu, Z. Ku, T. Liu, Y. Rong, M. Xu, M. Hu, J. Chen, Y. Yang, M. Graetzel and H. Han, Science, 2014, 345, 295-298.

36. J.-W. Lee, D.-J. Seol, A.-N. Cho and N.-G. Park, Advanced Materials, 2014, 26, 49914998.

37. Y. Yang, K. Ri, A. Y. Mei, L. F. Liu, M. Hu, T. F. Liu, X. Li and H. W. Han, Journal of Materials Chemistry A, 2015, 3, 9103-9107.

38. S. G. Hashmi, D. Martineau, M. I. Dar, T. T. T. Myllymaki, T. Sarikka, V. Ulla, S. M. Zakeeruddin and M. Gratzel, Journal of Materials Chemistry A, 2017, 5, 12060-12067.

39. F. Meng, A. Liu, L. Gao, J. Cao, Y. Yan, N. Wang, M. Fan, G. Wei and T. Ma, Journal of Materials Chemistry A, 2019, 7, 8690-8699.

40. D. A. Keller, H.-N. Barad, E. Rosh-Hodesh, A. Zaban and D. Cahen, Mrs Communications, 2018, 8, 1358-1362.

41. T.-S. Su, T.-Y. Hsieh, C.-Y. Hong and T.-C. Wei, Scientific Reports, 2015, 5.

42. J. M. Ball, S. D. Stranks, M. T. Hoerantner, S. Huettner, W. Zhang, E. J. W. Crossland, I. Ramirez, M. Riede, M. B. Johnston, R. H. Friend and H. J. Snaith, Energy \& Environmental Science, 2015, 8, 602-609.

43. H. Fujiwara, Spectroscopic Ellipsometry: Principles and Applications, Wiley, 2007.

44. T. B. Song, Q. Chen, H. P. Zhou, C. Y. Jiang, H. H. Wang, Y. Yang, Y. S. Liu, J. B. You and Y. Yang, Journal of Materials Chemistry A, 2015, 3, 9032-9050.

45. J. B. You, L. Meng, T. B. Song, T. F. Guo, Y. Yang, W. H. Chang, Z. R. Hong, H. J. Chen, H. P. Zhou, Q. Chen, Y. S. Liu, N. De Marco and Y. Yang, Nature Nanotechnology, 2016, 11, 75-+.

46. E. Zimmermann, K. K. Wong, M. Mueller, H. Hu, P. Ehrenreich, M. Kohlstaedt, U. Wuerfel, S. Mastroianni, G. Mathiazhagan, A. Hinsch, T. P. Gujar, M. Thelakkat, T. Pfadler and L. Schmidt-Mende, Apl Materials, 2016, 4. 
47. H. J. Snaith, A. Abate, J. M. Ball, G. E. Eperon, T. Leijtens, N. K. Noel, S. D. Stranks, J. T. W. Wang, K. Wojciechowski and W. Zhang, Journal of Physical Chemistry Letters, 2014, 5, 1511-1515.

48. S. A. Fateev, A. A. Petrov, V. N. Khrustalev, P. V. Dorovatovskii, Y. V. Zubavichus, E. A. Goodilin and A. B. Tarasov, Chemistry of Materials, 2018, 30, 5237-5244.

49. D. K. Owens and R. C. Wendt, Journal of Applied Polymer Science, 1969, 13, 1741-\&.

50. T. Oku, in Solar Cells, ed. L. A. Kosyachenko, IntechOpen, Rijeka, 2015, DOI: 10.5772/59284, ch. 3 . 


\section{Figures and tables}

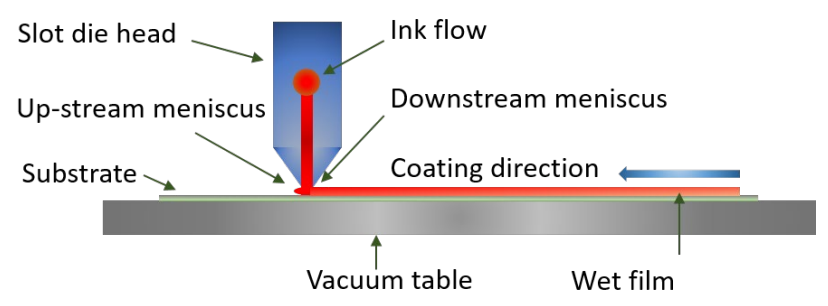

Fig. 1 Schematic representation of the process of slot die coating.

(a)

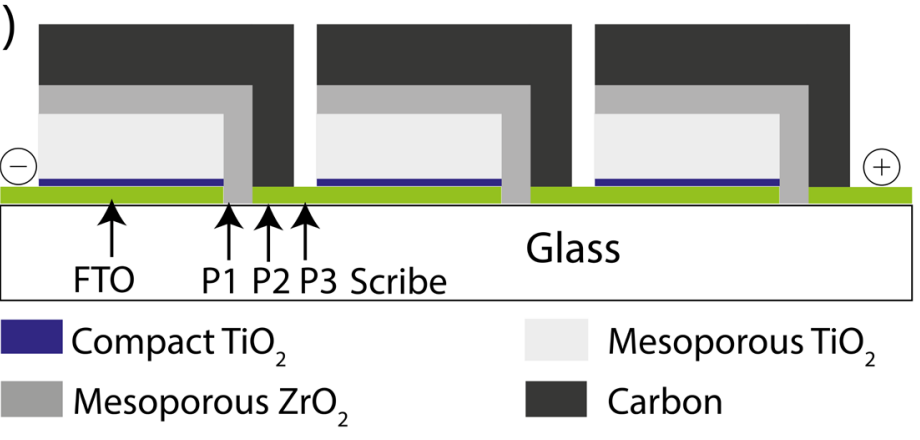

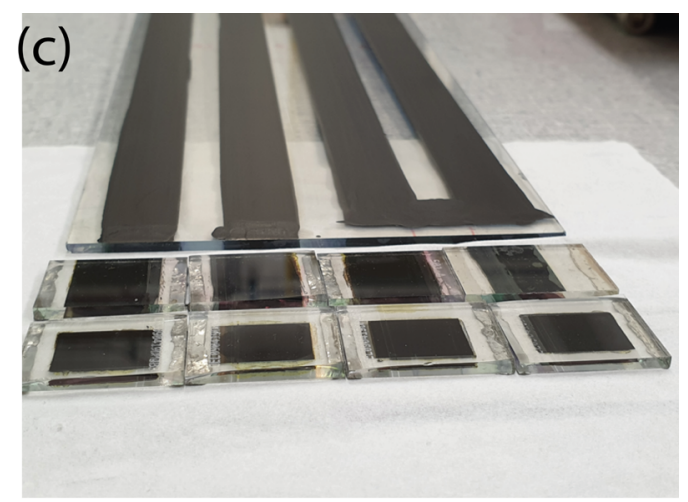

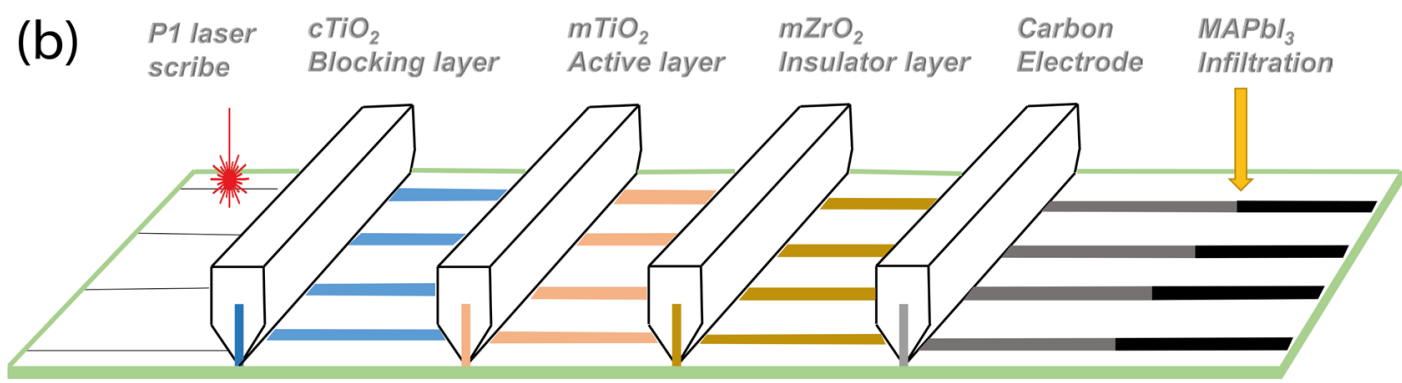

Glass Substrate

Fig. 2 (a) Cross-section of a MPSC module, indicating the different layers, as well as the serial connections between adjacent stripes. The connections can be realized by adapting stripe width and offset of the corresponding layers or by laser scribing. (b) Schematics of the processing steps of a fully slot die coated MPSC cell using stripe coating. Compact titania $\left(\mathrm{cTiO}_{2}\right)$, mesoporous titania $\left(\mathrm{mTiO}_{2}\right)$, mesoporous zirconia $\left(\mathrm{mZrO}_{2}\right)$ and carbon layer are sequentially slot die coated. In between the individual coating steps, the samples are dried as specified and only after the mesoporous multilayer film was completed, the entire stack is sintered all together (co-firing). In the last step the solar cell is completed by automatic infiltration of the $\mathrm{MAPbl}_{3}$ perovskite precursor solution. (c) Making of small area MPSC solar cells for characterization from stripe coated samples: glass pieces $25 \times 20 \mathrm{~mm}$ in size are cut from the substrates, an active cell area of $16 \times 12 \mathrm{~mm}$ is then defined by laser scribing. 

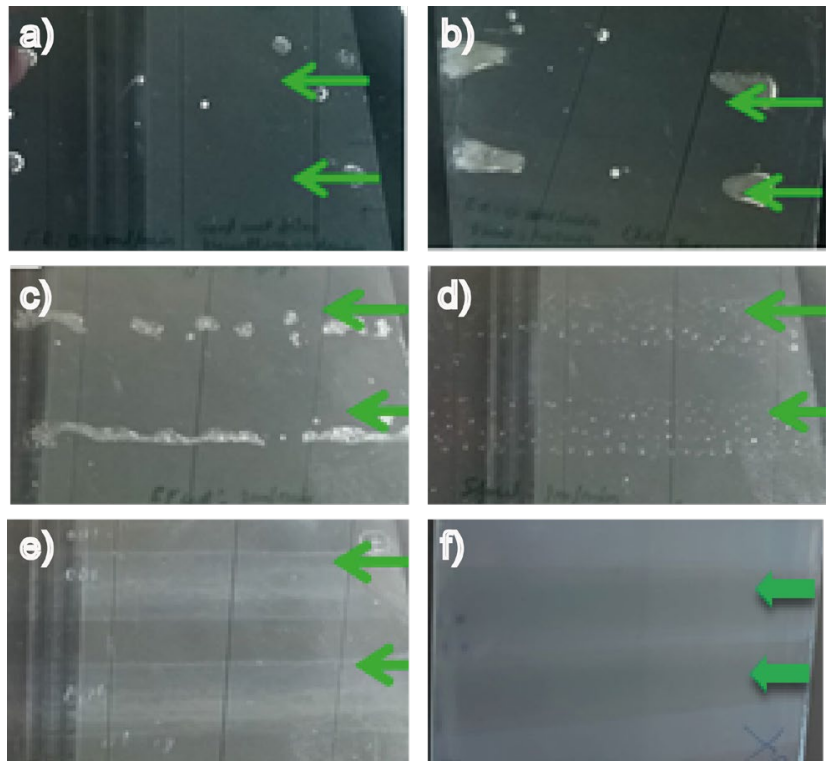

Fig. 3 Results of slot die coated stripe coatings (green arrows) after drying with the following inks. (a, b) TAA : tetralin 1:10 after single and double coating, respectively, (c ) TAA : tetralin : iPrOH 1:5:5, double coating, (d) TAA : tetralin : $\mathrm{PrOH}$ : EtOH 1:10:5:5, annealing at $70^{\circ} \mathrm{C}$, (e) TAA : tetralin : iPrOH : EtOH 3:20:20:20, annealing $70^{\circ} \mathrm{C}$, double coating, (f) TAA : tetralin : iPrOH : EtOH 3:20:20:20 + surfactant, annealing at $70^{\circ} \mathrm{C}$, double coating.
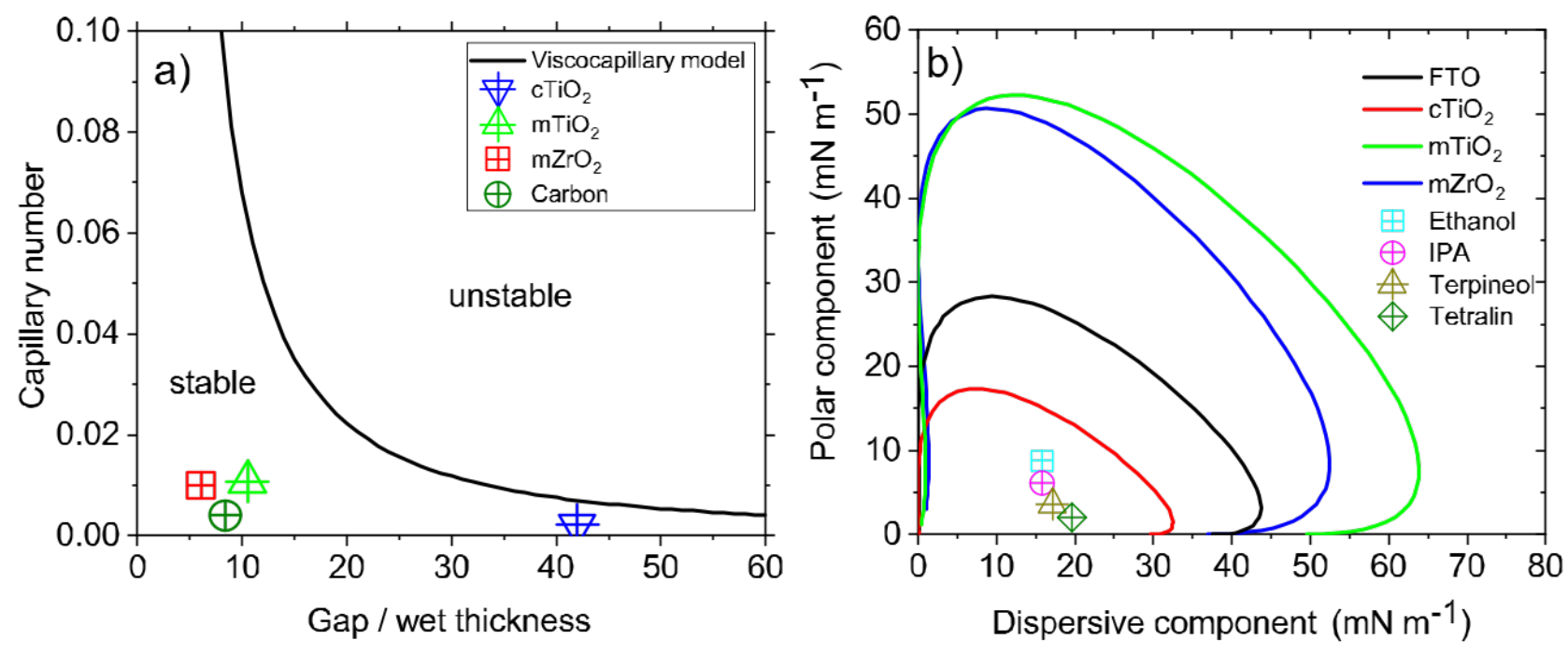

Fig. 4 (a) Critical capillary number and capillary numbers of slot die inks as function of gap to wet film thickness ratio. (b) Wettability envelope of the individual layers of a MPSC solar cell and surface energies of solvents used for ink formulation. 


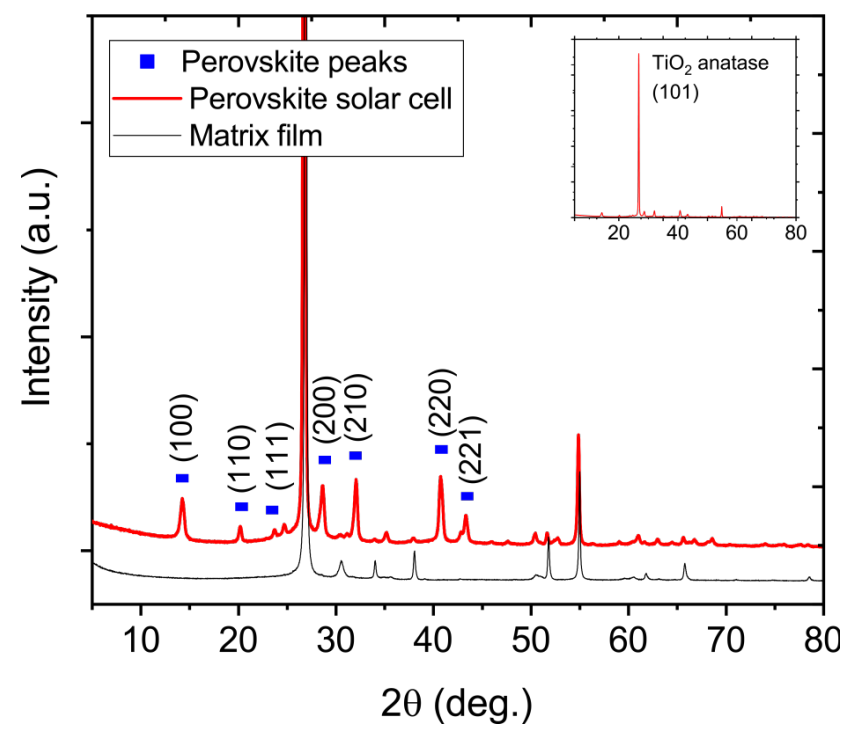

Fig. 5 X-ray diffraction patterns of the MSPC stack after MAPbl ${ }_{3}$ infiltration and annealing. The XRD spectrum is dominated by the (101) peak of $\mathrm{TiO}_{2}$ anatase at $2 \Theta=25.3^{\circ}$ (inset). A zoom into the peaks of lower intensity shows the characteristic peaks of the cubic phase of the perovskite crystal. ${ }^{50}$ No decomposition product of Perovskite into $\mathrm{Pbl}_{2}$ is present. $\mathrm{Pbl}_{2}$ would have a characteristic peak at $2 \Theta$ $=12.5^{\circ}$.
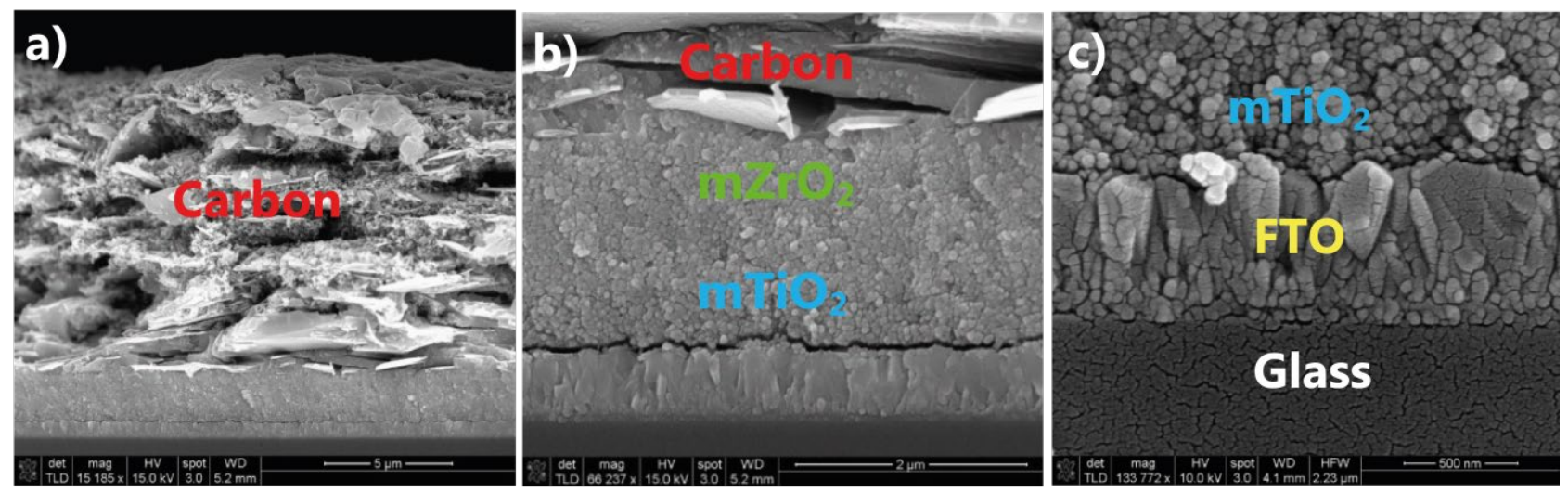

Fig. 6 Cross-sectional SEM images of fully slot die coated MPSCs. (a) Cross-section of the full stack. (b) Zoom into the metal oxide layers. (c) $\mathrm{FTO}-\mathrm{mTiO}_{2}$ interface. The $\mathrm{CTiO}_{2}$ layer is not visible. 


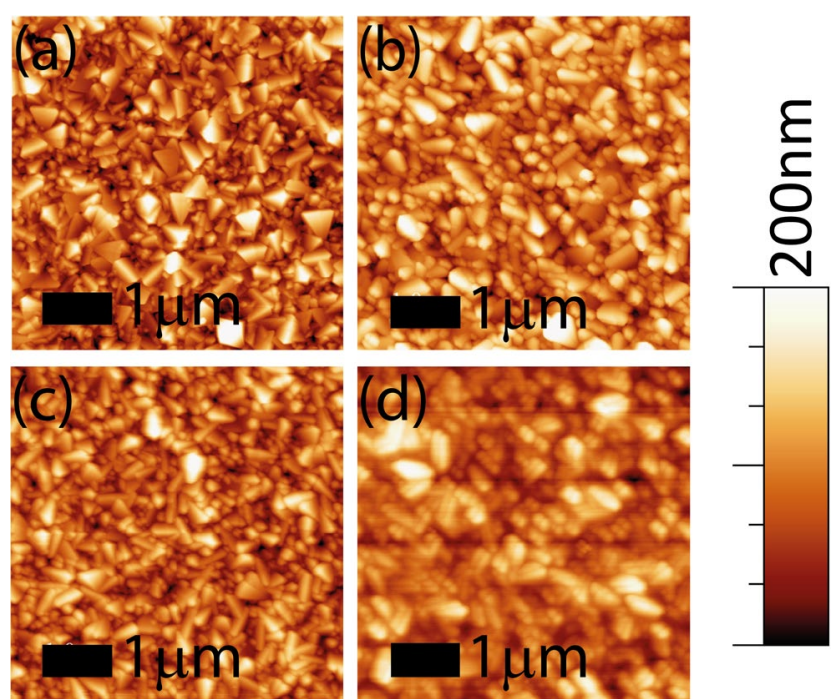

Fig. 7 Topographical images of FTO (a), and $\mathrm{cTiO}_{2}$ deposited onto FTO by spray pyrolysis (b), screen printing (c) and slot-die coating (d). All samples have been sintered.
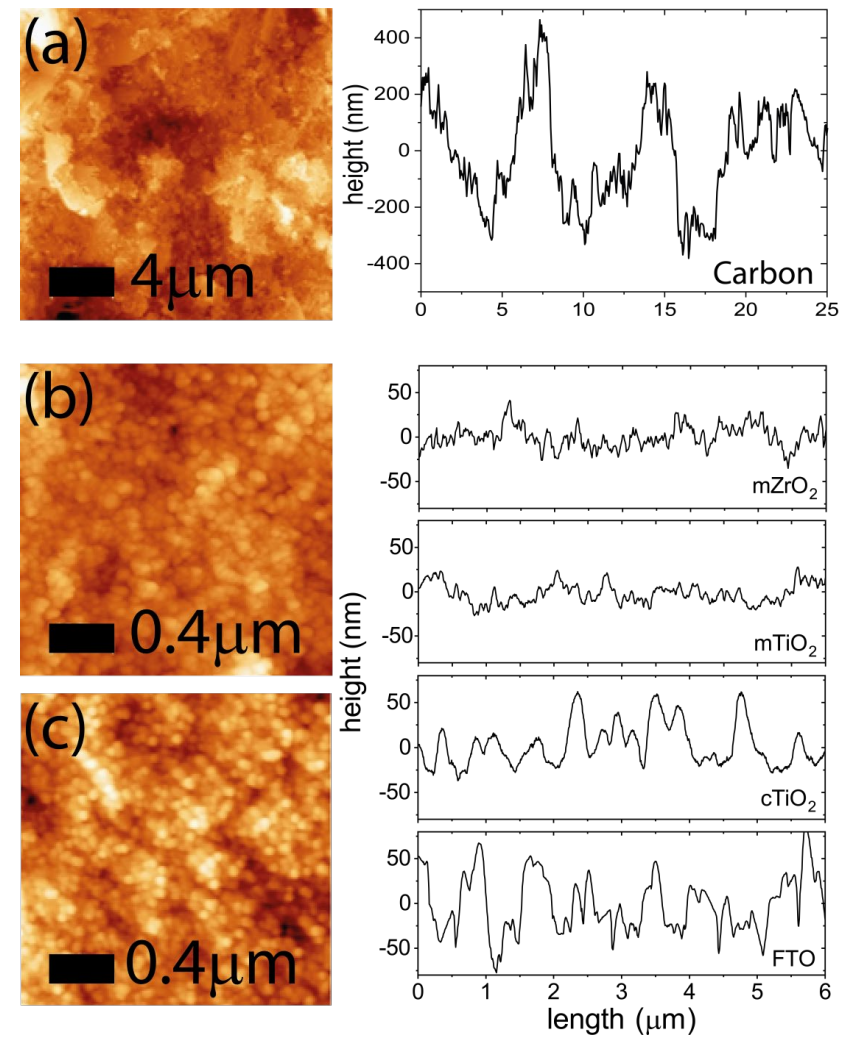

Fig. 8 Left: surface scans of (a) the carbon, (b) $\mathrm{mZrO}_{2}$ and (c) $\mathrm{mTiO}_{2}$ layer. Right: surface profiles from the AFM scans. 

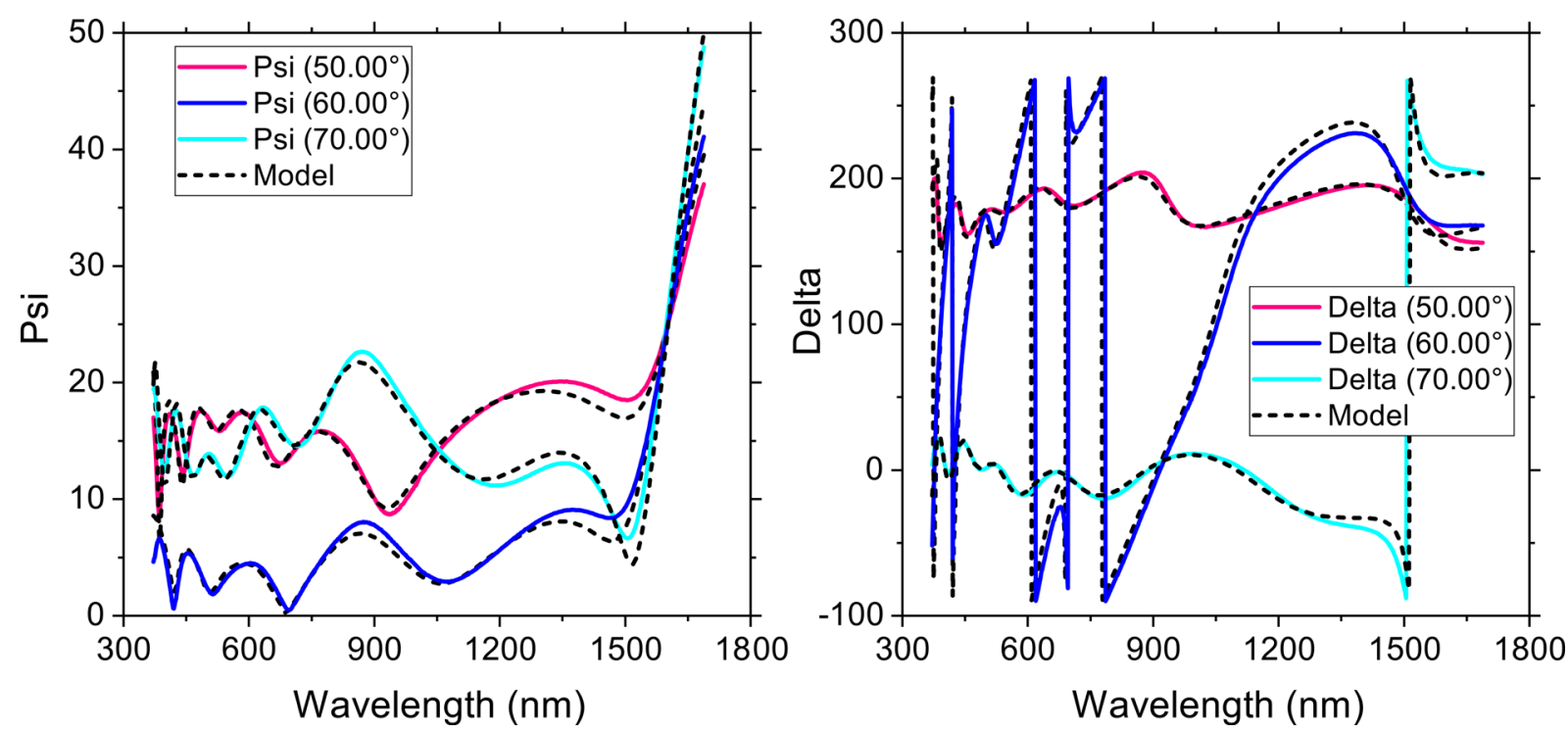

Fig. 9 Ellipsometric data for the three incidence angles (colored lines) and model fit (dotted lines). Left: Psi, right: Delta. 

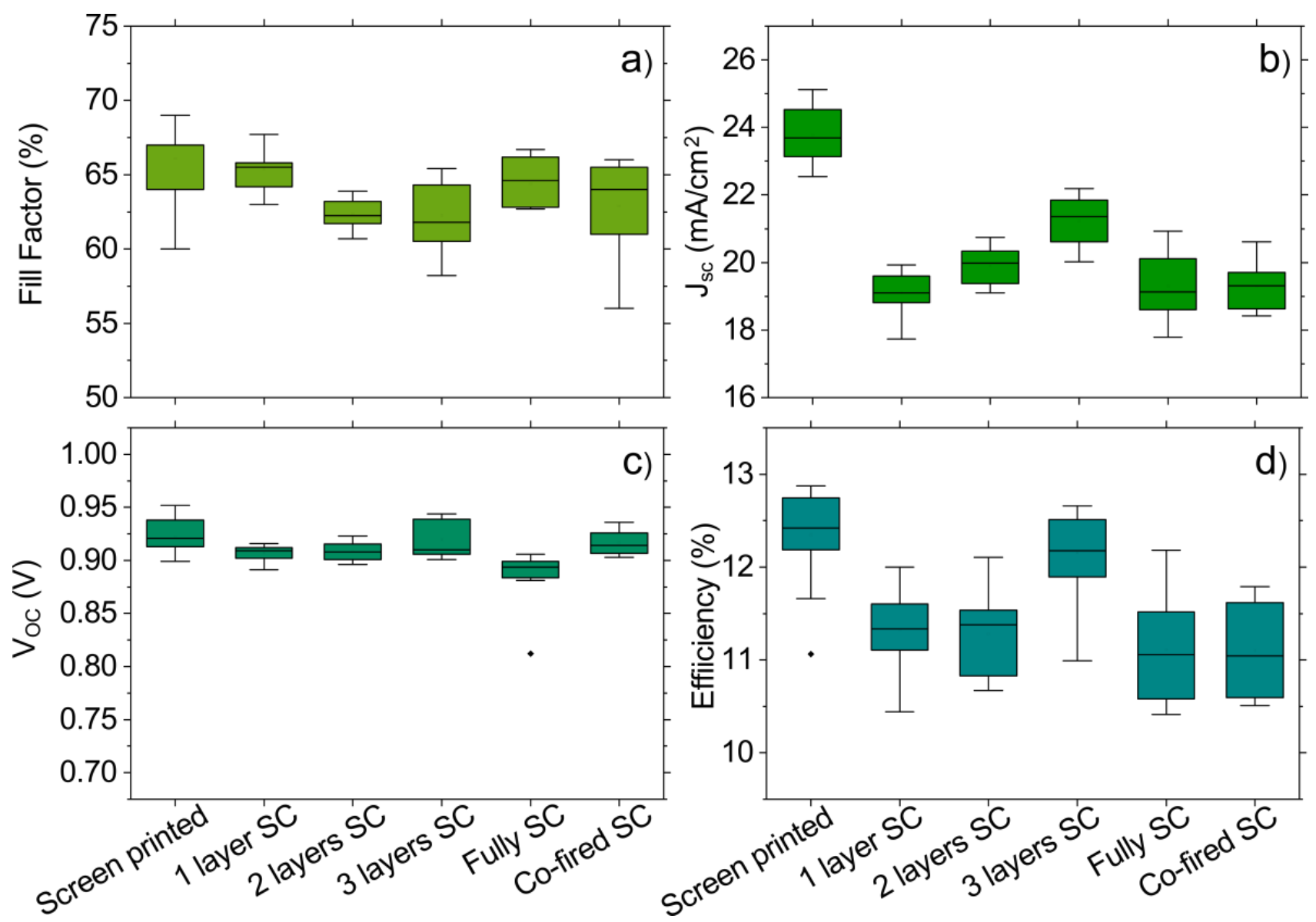

Fig. 10 Box plot of the device performance indicators for differently processed cells. (a) Fill factor. (b) Short circuit current $\mathrm{J}_{\text {sc. }}$ (c) Open circuit voltage $\mathrm{V}_{\text {oc. }}$ (d) Efficiency. The boxes represent the first and third quartiles, the horizontal black line the median, the upper whisker the data within 1.5 times the interquartile range of the upper quartile and the lower whisker 1.5 times the interquartile range of the lower quartile, black dots are the outliers. The data for each configuration are based on a number of independent cells, the number of cells is specified in Table 6 . 


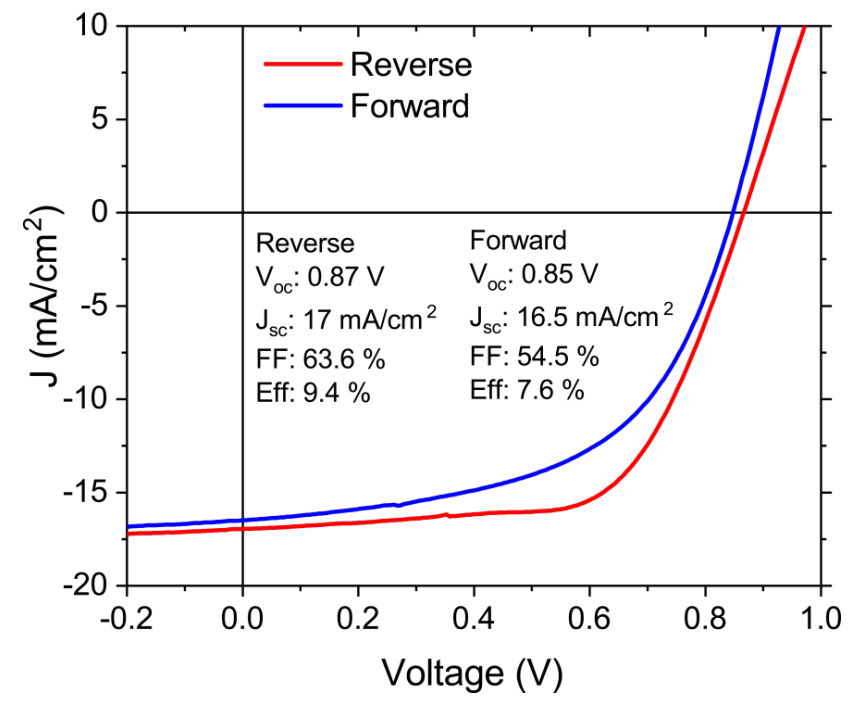

Fig. 11 J-V curves with forward and reverse scan of a typical fully slot die coated solar cell measured 23 months after manufacturing (non-encapsulated and stored under ambient conditions). The solar cell is not hysteresis-free.
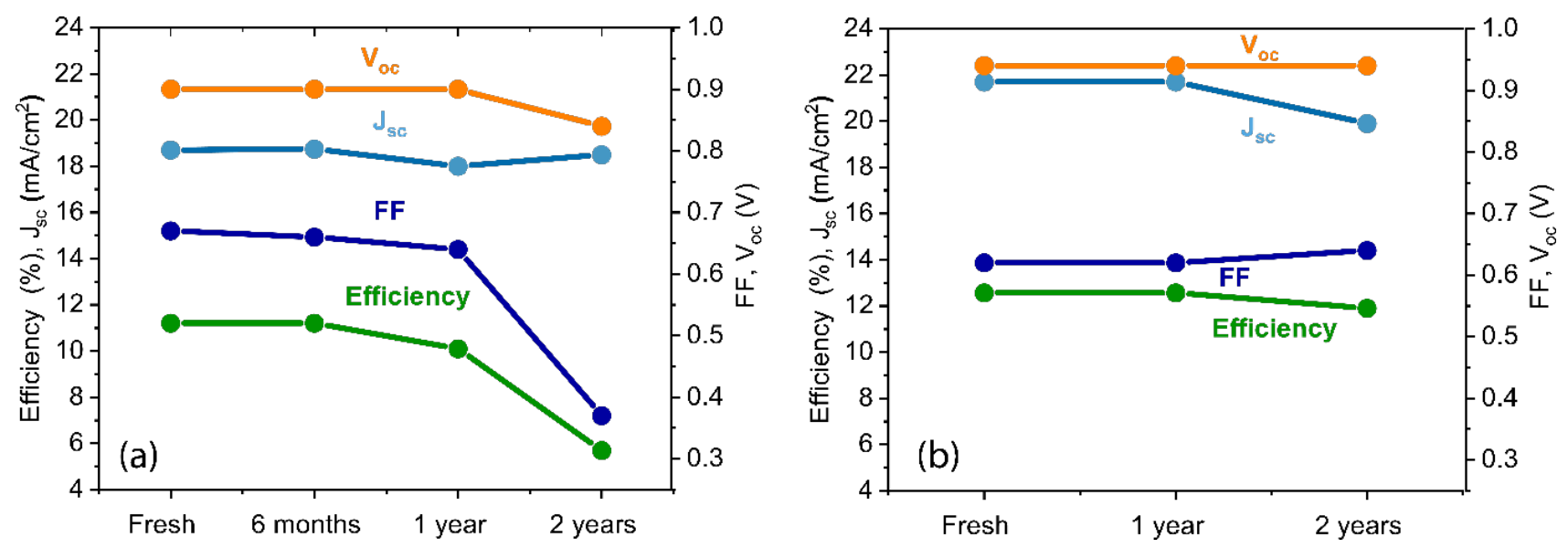

Fig. 12 Device performance indicators of (a) fully slot die coated cells without encapsulation (b) three layers slot die coated and encapsulated, after aging in ambient atmosphere at room-temperature. 
Table 1 Compositions and properties of the slot die coating inks developed in this study. The composition numbers relate to volume ratios; $\rho$ is the density, $\eta$ the viscosity and $\gamma$ the surface tension

\begin{tabular}{|c|c|c|c|c|}
\hline Ink & Composition & $\rho\left(\mathrm{g} / \mathrm{cm}^{3}\right)$ & $\eta$ (mPa.s) & $\gamma(\mathrm{mN} / \mathrm{m})$ \\
\hline Compact $\mathrm{TiO}_{2}$ & $\begin{array}{l}\text { TAA:tetralin:iPrOH:EtOH 3:20:20:20 } \\
\text { + surfactant }\end{array}$ & 0.85 & 2.79 & 22.5 \\
\hline Mesoporous $\mathrm{TiO}_{2}$ & Titania paste:terpineol:iPrOH 1:7:5 & 0.89 & 17.4 & 27.0 \\
\hline Mesoporous $\mathrm{ZrO}_{2}$ & Zirconia paste:iPrOH:EtOH 4:5:5 & 0.88 & 17.5 & 25.9 \\
\hline Carbon & Carbon paste:EtOH:iPrOH 2:1:1 & 0.90 & 36.8 & 23.4 \\
\hline
\end{tabular}

Table 2 Summary of the printing parameters and resulting dry film thicknesses for the slot die coating inks of Table 1. The capillary number $\mathrm{Ca}$ is calculated from eqn(1)

\begin{tabular}{lccccc}
\hline Ink & $\begin{array}{c}\text { Speed } \\
(\mathrm{m} / \mathrm{min})\end{array}$ & $\mathrm{Ca}$ & $\mathrm{h}_{\text {gap }} / \mathrm{h}_{\text {wet }}$ & $\begin{array}{c}\text { Flow rate } \\
(\mathrm{ml} / \mathrm{min})\end{array}$ & $\begin{array}{c}\text { Thickness } \\
(\mathrm{nm} \text {, double coating) }\end{array}$ \\
\hline Compact $\mathrm{TiO}_{2}$ & 1 & 0.0021 & 42 & 0.2 & 47 \\
Mesoporous $\mathrm{TiO}_{2}$ & 1 & 0.0107 & 10.5 & 0.8 & 550 \\
Mesoporous $\mathrm{ZrO}_{2}$ & 0.9 & 0.0101 & 6.1 & 1.25 & 1000 \\
Carbon & 0.2 & 0.0040 & 8.4 & 0.2 & $10.000-12.000$ \\
\hline
\end{tabular}

Table 3 Roughness parameters of $\mathrm{FTO}$ and the $\mathrm{CTiO}_{2}$ layers applied by spray pyrolysis, screen printing and slot die coating. $R_{q}$ is the root mean squared roughness, $R_{a}$ is the arithmetical mean deviation of the assessed profile

\begin{tabular}{lcccc}
\hline & $\mathrm{FTO}$ & $\mathrm{cTiO}_{2}$ : Spray Pyrolysis & $\mathrm{CTiO}_{2}$ : Screen print & $\mathrm{cTiO}_{2}$ : Slot die \\
\hline Image $\mathrm{R}_{\mathrm{q}}(\mathrm{nm})$ & 37.8 & 35.8 & 31.5 & 23.3 \\
Image $\mathrm{R}_{\mathrm{a}}(\mathrm{nm})$ & 29.6 & 28.5 & 25.1 & 18.5 \\
\hline
\end{tabular}

Table 4 Parameters of the simulation of the ellipsometer data for the $\mathrm{CTiO}_{2}$ layer on FTO glass.

\begin{tabular}{|c|c|c|c|c|}
\hline Layer & Material & Model & Data & $\begin{array}{l}\text { Thickenss } \\
(\mathrm{nm})\end{array}$ \\
\hline$\# 4$ & $\begin{array}{l}\mathrm{TiO}_{2} \text { and } \\
\text { VOID }\end{array}$ & TaucLor & $\begin{array}{l}\text { J.A.Wollam } \\
\text { database }\end{array}$ & 176.06 \\
\hline Intermix \# 3 / \# 4 & & EMA & & 43.34 \\
\hline \# 3 & FTO & $\begin{array}{l}\text { Oscillator wit Drude } \\
\text { term }\end{array}$ & Data fit & 361.40 \\
\hline$\# 2$ & $\mathrm{SiO}_{2}$ & Sellmeier & $\begin{array}{l}\text { J.A.Wollam } \\
\text { database }\end{array}$ & 25.00 \\
\hline \# 1 & $\mathrm{SnO}_{2}$ & General oscillator & $\begin{array}{l}\text { J.A.Wollam } \\
\text { database }\end{array}$ & 32.00 \\
\hline Substrate & Glass bare & Sellmeier & & \\
\hline
\end{tabular}


Table 5 Comparison of layer parameters (thickness and void content) for individually sintered and co-fired stacks.

\begin{tabular}{lccccc}
\hline Sintering & & $\mathrm{CTiO}_{2}$ & $\mathrm{mTiO}_{2}$ & $\mathrm{ZrO}_{2}$ & Roughness \\
Thickness $(\mathrm{nm})$ & layer-by-layer & 40 & 510 & 175 & 30 \\
& co-fired & 60 & 540 & 250 & 25 \\
\multirow{2}{*}{ Void content (\%) } & layer-by-layer & 25 & 50 & 55 & \\
& co-fired & 35 & 60 & 55 & \\
\hline
\end{tabular}

Table 6 Photovoltaic parameters of MPSCs with screen printed and slot die coated layers. $\mathrm{n}$ is the number of measured cells.

\begin{tabular}{|c|c|c|c|c|c|c|}
\hline & $\begin{array}{c}J_{\mathrm{sc}} \\
\left(\mathrm{mA} / \mathrm{cm}^{2}\right)\end{array}$ & $\begin{array}{l}V_{o c} \\
(V)\end{array}$ & $\begin{array}{l}\mathrm{FF} \\
(\%)\end{array}$ & $\mathrm{PCE}_{\text {avg }}(\%)$ & $\mathrm{PCE}_{\max }(\%)$ & $\mathrm{n}$ \\
\hline $\begin{array}{l}\text { Screen printed }(\mathrm{SC}) \text {, } \\
\text { (reference device) }\end{array}$ & 23.7 & 0.92 & 66.1 & 12.3 & 12.90 & 10 \\
\hline $\begin{array}{l}\text { Slot die coated compact } \\
\mathrm{TiO}_{2} \\
1 \text { layer SC }\end{array}$ & 19.1 & 0.91 & 65.4 & 11.3 & 12.01 & 13 \\
\hline $\begin{array}{l}+ \text { Slot die coated } \\
\text { mesoporous } \mathrm{TiO}_{2} \\
2 \text { layers } \mathrm{SC}\end{array}$ & 19.9 & 0.91 & 62.4 & 11.3 & 12.11 & 8 \\
\hline $\begin{array}{l}+ \text { Slot die coated } \\
\text { mesoporous } \mathrm{ZrO}_{2} \\
3 \text { layers } \mathrm{SC}\end{array}$ & 21.5 & 0.92 & 61.1 & 12.2 & 12.66 & 13 \\
\hline $\begin{array}{l}\text { All slot die coated } \\
\text { fully SC }\end{array}$ & 19.3 & 0.88 & 64.5 & 11.1 & 12.20 & 8 \\
\hline $\begin{array}{l}\text { All slot die coated, co- } \\
\text { fired } \\
\text { Co-fired SC }\end{array}$ & 19.3 & 0.92 & 62.9 & 11.1 & 11.80 & 8 \\
\hline
\end{tabular}

